\title{
O Problema da Tributação dos Lucros Extraordinários e Excessivos
}

\author{
Amilcar de ARaújo Falcão \\ (Assistente Jurídico do Ministério de Rela- \\ ções Exteriores)
}

\footnotetext{
$\mathrm{O}_{\mathrm{s}}$
}

impostos sôbre lucros extraordinários ou excessivos serão uma modalidade mais ou menos recente de tributação da renda cuja instituição, com as características de que se reveste a sua fórmula definitiva, remonta à Primeira Grande Guerra Mundial de 1914-18.

O impôsto, quer em países beligerantes, quer em países neutros, foi adotado geralmente em época de guerra, tanto para financiá-la, quanto para enfrentar problemas econômicos decorrentes da conjuntura de guerra. Algumas vêzes, contudo, o tributo tem sido criado em época de paz.

No Brasil, fêz-se uma experiência com o impôsto sôbre lucros extraordinários ou excessivos, em época de guerra e de após-guerra. reza.

No momento, surgiu a idéia de restabelecer uma tributação dessa natu-

Os aspectos que me proponho a examinar, a êsse último propósito, são os seguintes:

$1^{\circ}$ ) é possível, do ponto de vista técnico, instituir-se um impôsto de lucros extraordinários ou excessivos entre nós?

$\left.2^{\circ}{ }^{\circ}\right)$ será conveniente ou oportuna a instituição de tal modalidade de tributação, na quadra atual?

A tributação de lucros dessa espécie pode ocorrer sob duas diferentes modalidades:

a) o impôsto pode incidir, em determinado exercício fiscal, sôbre lucros que superem os auferidos em certo período ou exercício, de relativa normalidade por isso considerado ano-base ou período-base - a essa categoria pertencem os chamados impostos sôbre lucros extraordinários;

b) o impôsto pode incidir sôbre os lucros que superem a margem reputada razoável para a remuneração do capital empregado na sua produção dessa espécie são os chamados impostos sôbre lucros excessivos ou sôbre super-rendas no sentido estrito.

Ora, o impôsto sôbre lucros extraordinários pròpriamente dito é inaceitável e tem sido repelido pelos autores, dado que não leva em conta as perturbações, os sinistros, as perdas, as oscilações e flutuações casualties, wind- 
falls etc., dos americanos), de que podem ser vítimas as emprêsas no ano ou no período-base. A sua adoção, hoje, só se admite dentro de uma fórmula composita, conjugando-se alternativamente ao impôsto sôbre lucros excessivos, com o propósito de beneficiar o contribuinte. Assim sendo, isoladamente, o impôsto sôbre lucros extraordinários é imprestável e, combinado ou conjugado ao impôsto sôbre lucros excessivos, fica sob a dependência de ser êste tècnicamente possivel.

No nosso país, ainda caberia objetar à sua instituição o fato de inexistir um período de normalidade, ao menos relativa, que se pudesse considerar como período-base, para a aferição do cômputo comparativo dos lucros tributáveis, posto que os anos anteriores ou foram os de guerra, ou os de apósguerra, e, portanto, semelhantes aos primeiros, ou são os atuais, todos êles marcados por anormalidades na vida econômica do país.

Excluída, portanto, essa primeira modalidade de tributação, restará a segunda, ou seja, a do impôsto sôbre lucros excessivos.

Como se sabe, os impostos dessa espécie só são aplicáveis às pessoas jurídicas, sobretudo às emprêsas comerciais, industriais etc., tanto que alguns autores preferem incluí-los entre os impostos sôbre as atividades mercantís (business tax), embora sem desconhecer que, pela sua natureza, êles se situam no quadro geral da tributação da renda.

O certo é que a conceituação de um lucro como excessivo depende da fixação de uma margem razoável de remuneração das fôrças ou energias produtoras que o geraram.

No plano teórico, tem-se objetado que qualquer tentativa de fixar o conceito de lucros excessivos é empírica, e, como tal, cientificamente destituída de fundamento.

Contudo, na prática, é possível adotarem-se fórmulas de compromisso, para chegar-se a tal conceituação.

Mesmo assim, importa acentuar que a fixação dêsses lucros não pode ser feita sob um critério meramente quantitativo e sim mediante um critério qualitativo, sabido como é a correlação que existe entre o lucro e a natureza da emprêsa que o obteve. Há emprêsas que, com um diminuto capital, podem auferir lucros proporcionalmente a êle excessivos, se não se levar em conta a atividade individual, o trabalho desenvolvido pelos empresários, como é o caso dos negócios de representação e agenciamento, das firmas que exploram a prestação de serviços técnicos etc.

Nessa ordem de considerações, a tributação só seria admissível se o legislador descesse a um casuismo extremo, passando a fixar a situação de cada tipo de emprêsa. Por isso mesmo, pela complexidade que se instauraria na aplicação do tributo, êle já não seria recomendável.

Mas, encarando a situação do nosso país, a conclusão a que se chega é a da impossibilidade técnica de criar-se um impôsto sôbre lucros excessivos.

$\mathrm{E}$ isto por uma razão simples.

E que, nos últimos tempos se inaugurou uma política absolutamente desordenada de reavaliações de ativo, sem que para a efetuação destas, houvesse a mínima orientação e fiscalização. 
Assim sendo, houve firmas que reavaliaram imoderadamente os seus ativos, ensejando verdadeira aguagem do capital social. Outras o fizeram de modo discreto ou moderado, e outras, enfim, deixaram de servir-se da faculdade de reavaliação.

Como, então, saber-se qual é o verdadeiro capital das emprêsas, a fim de dar-1he tratamento equânime?

Resulta daí que uma tributação de lucros excessivos, à falta dêsse presuposto ou componente da equação pela qual êles se aferem, é impossível, sob pena de ocasionar-se um profundo tumulto na vida econômica nacional, com a penalização e, mesmo, a própria destruição de inúmeras emprêsas, em proveito de outras tantas.

A tributação da renda pelo critério do montante relativo do lucro, como é o caso do impôsto sôbre lucros excessivos, é, pois, tècnicamente inaceitável entre nós, além do mais, por fôrça dessa circunstância - o desconhecimento da verdadeira consistência do ativo das emprêsas.

Fica demonstrada a primeira das proposições a cujo exame nos entregamos: a da impossibilidade, do ponto de vista técnico ou científico, de instituir-se no Brasil um impôsto sôbre lucros extraordinários, ou excessivos.

Sem embargo do que se acabou de discutir, importa verificar se conviria a instituição do tributo.

Êste, segundo se alega, teria uma finalidade fiscal, de aumentar a arrecadação da receita federal. Ao lado dessa, avultam as finalidades extra-fiscais de enfrentar a conjuntura, ensejar maior justiça fiscal mediante a redistribuição de rendimentos, obstar à especulação, etc..

Ora, o primeiro objetivo não seria alcançado. A instituiçãa lo impôsto, como tem demonstrado a experiência, iria estimular a evasão inclusive do impôsto sôbre a renda. E curioso verificar que o próprio fisco não deseja a sua criação. Quando recentemente se debateu a matéria no Instituto Brasileiro de Direito Financeiro, duas vozes autorizadíssimas, as de Tito Rezende e Castro Viana, êste último Diretor da Divisão do Impôsto de Renda, pronunciaram-se em tal sentido.

Convém assinalar que, com a só tramitação do projeto na Câmara $\mathrm{Fe}$ deral, já diminuiu a arrecadação do impôsto de renda.

Uma vez sancionada a lei, a arrecadação conjunta do impôsto de renda e de lucros extraordinários ou excessivos somada, fatalmente será inferior à normal arrecadação do primeiro, tal, volume que atingirão a evasão e as despesas fraudulentas ou de dissipação, para fugir à incidência.

Se a finalidade fiscal fica assim frustada, não se pode dizer outra coisa das finalidades extrafiscais.

E preciso atentar para a origem dos chamados lucros extraordinários ou excessivos.

Num quadro geral, êles podem ter três procedências: a guerra, o monopólio e a existência de certos fatôres de competição imperfeita, encontradiços nos países sub-desenvolvidos, como o nosso. 
A primeira hipótese não nos interessa.

Quanto à segunda, é sabido que a matéria não se resolve pela via fiscal, absolutamente impotente para tanto devendo ser solucionada pela lei penal ou, como dizem os autores americanos, pela anti-trust division.

Resta a última hipótese. Melhorias técnicas e de mão-de-obra podem ensejar lucros maiores. Esses fatôres não ocorrem nos países desenvolvidos, dado que, uma vez surgidos, imediatamente, tôdas as demais emprêsas passam a adotá-los. Nos países sub-desenvolvidos como o nosso, porém, êles são muito comuns, pela existência de inúmeros fatores de estrangulamento, que momentâneamente põem em posição favorável determinadas emprêsas.

O certo, entretanto, é que os lucros maiores que daí procedem, antes de serem penalizados devem ser estimulados, a fim de que sirvam como elemento excitador da melhoria da produção.

Vê-se, conseqüentemente, a inconveniência que, no particular, acarretaria essa modalidade de tributação.

Do ponto de vista da justiça fiscal, também não se recomenda aquela. Já se disse que a real consistência do lucro tem que ser determinada em função do tipo de cada emprêsa e da modalidade de atuação a que ela se entregue. Há emprêsas em que é maior a incidência do capital na formação do lucro, como há outras tantas em que o fator preponderante é o trabalho, sendo diminuta a influência do capital.

A discriminação de cada caso é pràticamente impossível, de modo que a instituição do tributo em condições de funcionar iria ocasionar as maiores injustiças.

Restaria o problema do estabelecimento de um freio para a especulação. Já se demonstrou que a evasão retiraria uma porção considerável dos efeitos que sôbre a especulação pudessem produzir-se. Demais ante todos os inconvenientes apontados anteriormente talvez fôsse melhor pensar-se, com êsse objetivo, em outra fórmula, que tem produzido bons resultados no direito comparado e que entre nós seria menos perturbadora qual a da criação do impôsto de consumo com alíquotas em escala móvel, mediante lei de habilitação do Congresso.

São essas as considerações que a propósito achei oportuno desenvolver.

O impôsto examinado parece não ser tècnicamente passível de instituição entre nós, e, demais disso, a sua criação, na quadra atual, seria inconveniente e inoportuna.

GROvEs, estudando o problema do excess profits tax, afirma que êle constitui um exemplo de falência da técnica administrativa e contábil para a concretização de um objetivo desejável.

Encarada, especial e particularmente, a realidade brasileira, não seria impetuoso que se insistisse com maior ênfase nessa assertiva e se concluísse mesmo pela própria impossibilidade de adotar qualquer fórmula racional e tècnicamente tolerável. 